\title{
Cerebral Vasomotor Reactivity in Medically Stabilized Patients with Takayasu's Arteritis
}

\author{
Takayasu Arteritinde Stabil Hastalık Döneminde Serebral Vazomotor Reaktivite
}

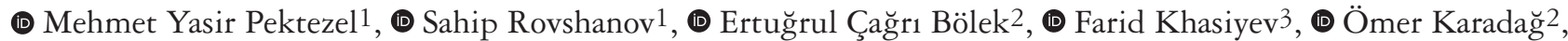 \\ (1) Ethem Murat Arsava1, (1) Mehmet Akif Topçuoğlu ${ }^{1}$ \\ 1Hacettepe University Faculty of Medicine, Department of Neurology, Neurology Intensive Care Unit, Ankara, Turkey \\ 2Hacettepe University Faculty of Medicine, Department of Internal Diseases, Division of Rheumatology, Ankara, Turkey \\ ${ }^{3}$ St. Louis University School of Medicine, Department of Neurology, Missouri, USA
}

\begin{abstract}
Objective: Takayasu arteritis (TA) is a large vessel vasculitis that affects the aorta and its main branches in the young population. Although data about the effects of controlling disease activity with immunosuppressive treatments on cerebral circulatory capacity are limited, these treatments might stabilize the cerebrovascular hemodynamic status, regardless of the severity of proximal arteriopathy. One of the causes might be the normalization of cerebral autoregulation by the treatment. Materials and Methods: Cerebral vasomotor reactivity (cVMR) was calculated using the breath holding index (BHI) after bilateral middle cerebral artery (MCA) flow pattern was detected using transcranial Doppler ultrasound (TCD) in six patients with TA who were stabilized with treatment (age: $29 \pm 7$ years, 5 female). A total of 28 measurements were performed. The control group included 18 healthy volunteers, except for migraine ( $29 \pm 6$ years, 12 female). Bilateral MCA mean flow rates (Vmean, $\mathrm{cm} / \mathrm{s}$ ), pulsatility indexes (PI) and BHI were compared using non-parametric statistical methods.

Results: Middle cerebral artery Vmean and PI values were lower in patients with TA $(48.3 \pm 17.2 \mathrm{~cm} / \mathrm{s}$ and $0.31 \pm 0.16$, respectively) compared with the controls $(62.2 \pm 11.3$ and $0.70 \pm 0.11$, respectively) (both $\mathrm{p}<0.001$ ). BHI was measured as $0.92 \pm 0.63$ in the TA group and $0.93 \pm 0.38$ in the controls ( $\mathrm{p}=0.97$ ). Additionally, in the TA group, TCD parameters measured in the occluded carotid artery territory (11 tests) did not differ from those measured in the non-occluded parent carotid artery territory.
\end{abstract}

Conclusion: It seems that cVMR can be stabilized at least in the medium range in patients with TA. A protected or improved cerebral microcirculation in patients with TA, unlike in patients with atherosclerotic cervicocephalic artery occlusions, might be an explanation.

Keywords: Takayasu's arteritis, cerebral vasomotor reactivity, breath holding test

Öz

Amaç: Takayasu arteriti (TA) genç yaşlarda arkus aorta ve dallarının tutulumu ile karakterize bir büyük damar vaskülitidir. İmmünosüpresif tedaviler ile hastalık aktivitesinin kontrol altına alınmasının serebral dolaşım üzerine etkisi konusunda yayınlar oldukça sınırlı olup, bu tip tedaviler ile proksimal arteriopati sekeline karşın serebrovasküler hemodinamik status stabilize edilebilmektedir. Bunun nedenlerinden biri serebral mikrosirkülatuvar otoregülatuvar kapasitenin tedavi ile normale dönüşü olabilir.

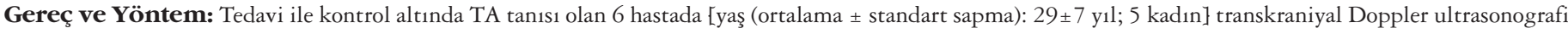
(TCD) ile her iki orta serebral arter (OSA) akım paterni tespit edildikten sonra nefes tutma indeksi (NTI) ile serebral vazomotor reaktivite (sVMR) çalışıldı. Altı hastada toplam 28 sVMR ölçümü yapıldı. Kontrol grubu migreni olması dışında sağlıklı olan 18 kişiden oluşturuldu (yaş: $29 \pm 6$ yıl; 12 kadın). Her iki taraf OSA ortalama akım hızı (Vortalama, cm/s), pulsatilite indeksi (PI) ve NTI değerleri non-parametrik istatistiksel yöntemlerle karşılaştırıldı.

Bulgular: OSA Vortalama ve PI değerleri sırasıyla, TA grubunda $48,3 \pm 17,2 \mathrm{~cm} / \mathrm{s}$ ve $0,31 \pm 0,16$ olup kontrol grubundan $(62,2 \pm 11,3 \mathrm{~cm} / \mathrm{s}$ ve $0,70 \pm 0,11)$ düşük olarak saptand1 (her iki; $\mathrm{p}<0,001$ ). NTI TA grubunda $0,92 \pm 0,63$ ve kontrollerde ise $0,93 \pm 0,38$ olarak ölçüldü ( $\mathrm{p}=0,97$ ). Ek olarak TA grubunda oklüde ana karotid arter sahasında (11 test) çalı̧̧ılan TCD ölçümleri ana karotis arteri oklüde olmayan hastalara ait ölçümlerden farklilık göstermedi.

Sonuç: TA olan hastalarda, sVMR tedavi sonrası en azından orta erimde stabil hale gelmektedir. Serebral mikrosirkülasyonun, aterosklerotik servikoserebral arter oklüzyonlarındakinin aksine, korunmuş olması veya tedavi sonrası düzelmesi bu durumun açıklaması olabilir.

Anahtar Kelimeler: Takayasu arteriti, serebral vazomotor reaktivite, nefes tutma testi

Address for Correspondence/Yazışma Adresi: Mehmet Akif Topçuoğlu MD, Hacettepe University Faculty of Medicine, Department of Neurology, Neurology Intensive Care Unit, Ankara, Turkey

Phone: +90 3123051806 E-mail: mat@hacettepe.edu.tr ORCID: orcid.org/0000-0002-7267-1431

Received/Geliş Tarihi: 23.10.2020 Accepted/Kabul Tarihi: 06.12.2020

${ }^{\circ}$ Copyright 2021 by Turkish Neurological Society

Turkish Journal of Neurology published by Galenos Publishing House. 


\section{Introduction}

Takayasu arteritis (TA) is a large vessel vasculitis characterized by inflammatory involvement of the aorta and its branches that affects the young population (1). Neurologic symptoms and signs secondary to involvement of large vessels such as internal carotid artery and subclavian artery can be seen in $50 \%$ of patients with TA (2). In the course of TA, secondary to the presence of proximal arteriopathy, indirect intracranial vascular pathologic changes have also been demonstrated $(3,4,5)$. There are small studies about the partial stabilization of this cerebrovascular haemodynamic effect with immunosuppressive-biologic agents currently used in TA treatment or various surgical treatment options $(5,6,7,8)$, but the response of this situation in terms of cerebral vasomotor reactivity (cVMR) is not clearly known. In our study, we investigated whether cVMR values measured using the breath-holding test (BHT) in transcranial Doppler ultrasonography (TCD) in patients with TA in the stable period after treatment were different from those of healthy adults (control group).

\section{Materials and Methods}

\section{Patients}

All patients with TA who were aged $>18$ years, followed up and stable under treatment, and were referred to our neurosonology laboratory for evaluation with the BHT for cerebrovascular risk for various reasons (e.g. drug discontinuation, periprocedural risk) between 2016-2020 in Hacettepe Medical Faculty Vasculitis Diagnosis and Treatment Research and Application Center, were included in this retrospective analysis. Vascular examinations such as neuroimaging and digital subtraction angiography, computed tomography angiography, magnetic resonance angiography, and demographic data, additional diseases, and medications used were obtained from the hospital's electronic data system. The control group consisted of adults with normal neurologic examinations and without any additional disease other than migraine (9). BHT of both groups was performed using TCD in the Neurosonology Laboratory of Hacettepe University. This retrospective analysis of a previous study in which a control group was included (9) was approved by the Hacettepe University Ethics Committee (project no: 20/903, decision no: 2020/16-24).

\section{TCD Breath-holding Test}

The TCD examination was performed using the MultiDop ${ }^{\circledR}$ (DWL Compumedics, Singen, Germany) device and its $2 \mathrm{MHz}$ head stabilized monitoring probes. During the evaluation, patients were kept in a $30^{\circ}$ supine position. Middle cerebral artery monitoring was fixed at a depth of $45-50 \mathrm{~mm}$. BHT was performed by repeating 30-second breath-holding periods at least twice. Normal inspiratory-expiratory cycles were allowed before each BHT series so that the apnea period during BHT and the effect of Valsalva did not disturb the second phase of the other BHT episodes. BHT measurements were considered valid if the apnea time was $>24 \mathrm{sec}$. Triphasic TCD waveforms were evaluated throughout the BHT (9).

The normal BHT response includes the phase of transient flow velocity increase usually occurs in 5 seconds at the beginning of the test (phase 1), phase 2 where a decrease (negative) in maximum flow velocity occurs during apnea (pit response), and phase 3 in which the flow velocity increases immediately within 2-4 seconds after the cessation of apnea and continues normally for a long time (apnea response) (9). Peak systolic velocity (PSV), end-diastolic velocity $(\mathrm{EDV})$, mean flow velocity $[\mathrm{Vmean}=\mathrm{EDV}+(\mathrm{PSV}-\mathrm{EDV}) / 3]$, pulsatility index $[\mathrm{PI}=(\mathrm{PSV}-\mathrm{EDV}) / \mathrm{Vmean}]$ and time between pit and apnea response phases (breath-holding period) were determined. The BHT was calculated as the percentage increase of apnea mean velocity relative to the baseline value divided by the duration of the breath-hold in seconds $[\mathrm{BHT}=(\mathrm{V}$ mean apneaVmean baseline) $\mathrm{x}$ 100/Vmean baseline $\mathrm{x}$ duration of breath-hold] (Figure 1, 2).

\section{Statistical Analysis}

The data were analyzed using the SPSS 23 IBM $^{\circledR}$ package provided free of charge by Hacettepe University Faculty of Medicine. The mean values of the groups were appropriately

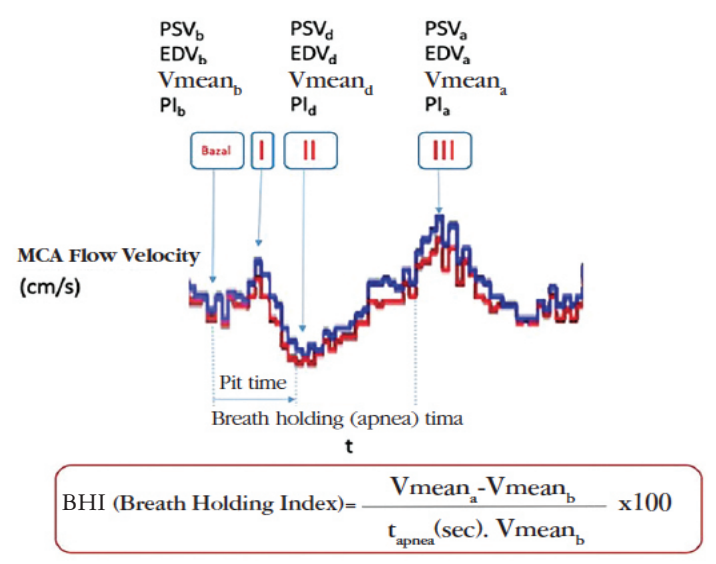

Figure 1. MCA flow-time graph and BHI Formula in TCD recording during the Breath-holding test

MCA: Middle cerebral artery, BHI: Breath-holding index, TCD: transcranial Doppler ultrasound, Vmean: Mean flow rates, PSV: Peak systolic velocity, EDV: End-diastolic velocity

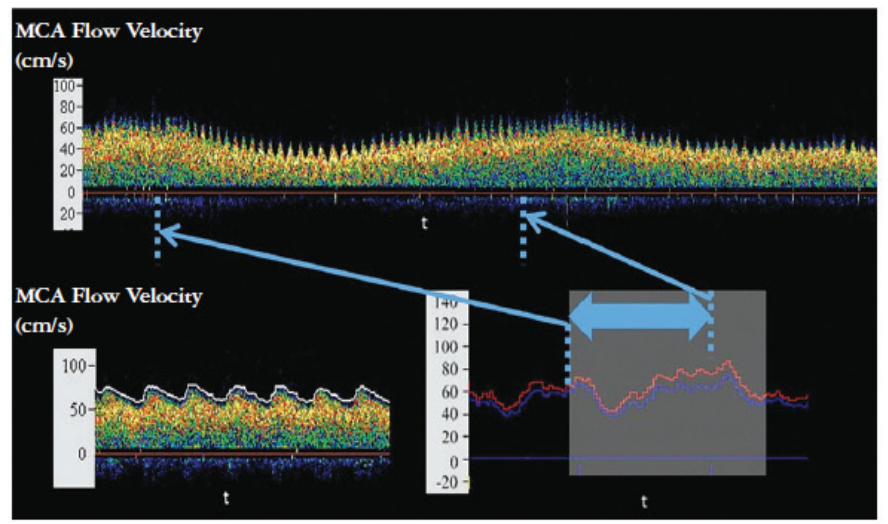

Figure 2. Original BHI Study Example (top: Compressed MCA flow-time graph, Bottom left: MCA PSV and EDV values in uncompressed MCA flow-time graph, Bottom right: Basal, pit and apnea response phases of BHT)

BHI: Breath-holding index, MCA: Middle cerebral artery, PSV: Peak systolic velocity, EDV: End-diastolic velocity 
expressed as mean \pm standard deviation or median \pm interquartile range. Student t-test or the Mann-Whitney $U$ test was used for parametric data for comparisons between groups, and the chisquare/Fisher's exact test was used for categorical data. A value of $\mathrm{p}<0.05$ was considered statistically significant.

\section{Results}

The data of six patients with TA (Table 1,2) and 18 healthy volunteers were analyzed. The mean age of the TA group was $29 \pm 7$ years (five women), and the control group was $29 \pm 6$ years (12 women). The MCA Vmean and PI values were $48.3 \pm 17.2 \mathrm{~cm} / \mathrm{s}$ and $0.31 \pm 0.16$ in the TA group, $62.2 \pm 11.3 \mathrm{~cm} / \mathrm{s}$ and $0.70 \pm 0.11$ in the control group, respectively (both $\mathrm{p}<0.001$ ). No difference was found between the two groups in terms breath-holding (BHI) measurements $(0.92 \pm 0.63$ vs. $0.93 \pm 0.38, \mathrm{p}=0.97)$ (Table 3).

When the TA patient group was evaluated according to whether the parent artery was occluded $[\mathrm{O}(+)$ vs. O (-)], 11 out of a total of 28 measurements were found to be studied on the side of the occlusion of the parent artery. In these measurements, there was no difference between the groups in terms of PSV, EDV, Vmean, PI, and BHI values (Table 4).

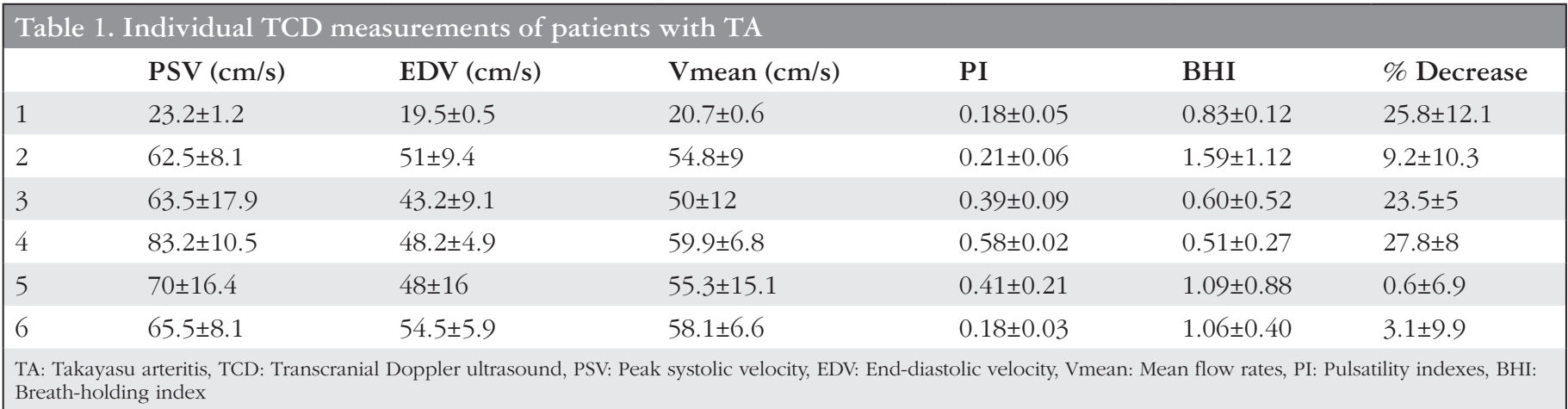

Table 2. General data of patients with TA

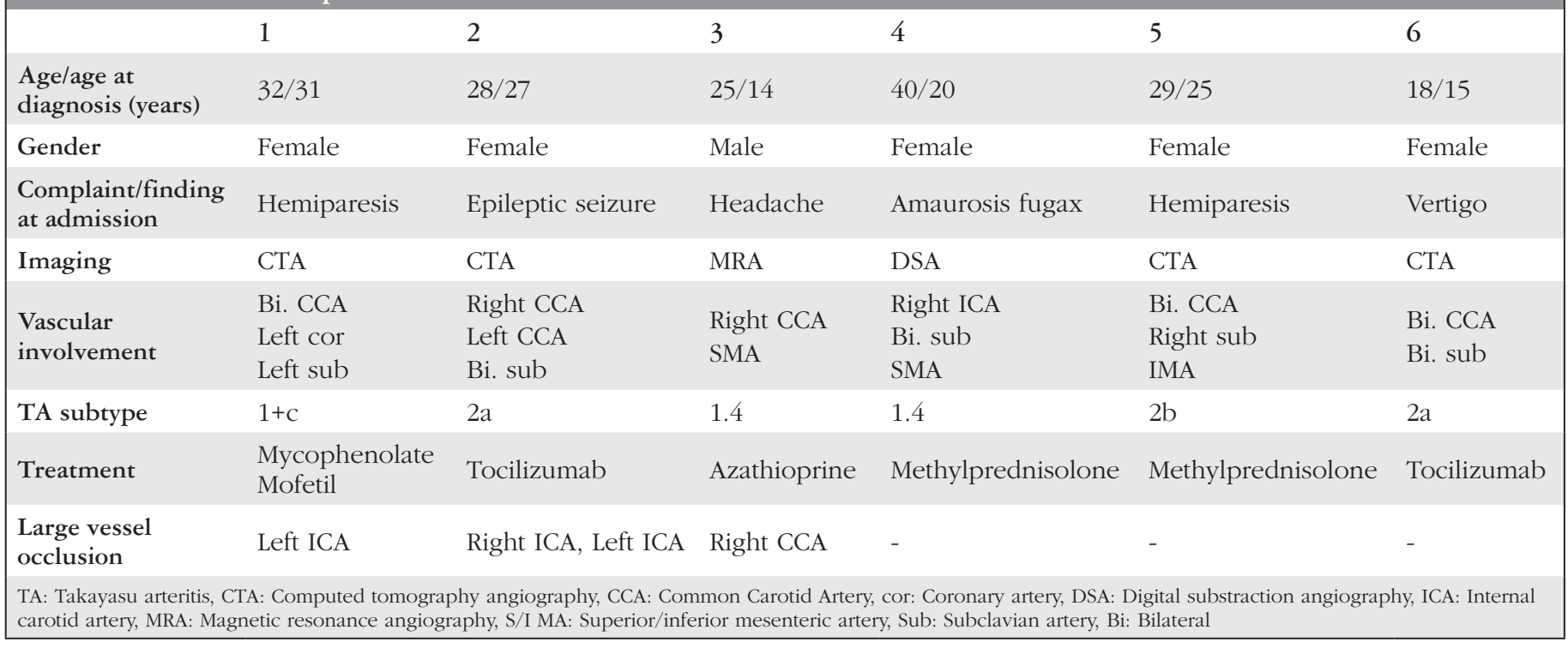

Table 3. Comparison between patients with TA and controls

\begin{tabular}{|llll|} 
& TA & Control & p \\
N & 6 & 18 & - \\
Year (year) & $29 \pm 7$ & $29 \pm 6$ & 0.91 \\
Gender (F) & 5 & 12 & 0.62 \\
MCA Vmean (cm/s) & $48.3 \pm 17.2$ & $62.2 \pm 11.3$ & $<0.001$ \\
MCA PI & $0.31 \pm 0.16$ & $0.70 \pm 0.11$ & $<0.001$ \\
BHI & $0.92 \pm 0.63$ & $0.93 \pm 0.38$ & 0.97 \\
BHI: Breath holding Index, MCA: Middle cerebral artery, PI: Pulsatility index, TA: Takayasu arteritis, Vmean: Mean flow rates \\
\hline
\end{tabular}




\begin{tabular}{|c|c|c|c|}
\hline & $\mathrm{O}(+)$ & $\mathrm{O}(-)$ & $\mathrm{p}$ \\
\hline $\operatorname{PSV}(\mathrm{cm} / \mathrm{s})$ & $52.3 \pm 21.5$ & $63.2 \pm 22.8$ & 0.14 \\
\hline $\operatorname{EDV}(\mathrm{cm} / \mathrm{s})$ & $41.6 \pm 17.3$ & $44 \pm 14.5$ & 0.63 \\
\hline BHI & $1.2 \pm 0.7$ & $0.85 \pm 0.5$ & 0.26 \\
\hline
\end{tabular}

\section{Discussion}

In the literature, "pulseless spectrum" ipsilateral with extracranial pathology, decreased flow velocity and PI, microembolic signal, and collateral flow reorganization were described in TCD examinations in patients with TA (10), and in our series, "pulseless spectrum", decreased flow velocity, and decreased PI were found, in accordance with the literature.

When evaluated in terms of treatment, it has been shown that the "pulseless" condition can disappear in half of all patients with TA after steroid treatment (6). In patients with TA, stabilization or reduction in vessel wall thickness and diameter can be demonstrated in carotid Doppler examinations after treatment with immunosuppressive agents such as azathioprine and mycophenolate mofetil (11). In addition, flow velocity and PI normalizations in TCD in patients with TA after surgical treatment of large vessels were described at the case report level $(5,7,8)$.

It is striking that there are not many studies in the literature regarding sVMR in patients with TA. When the literature is reviewed in this respect, case reports are showing decreased CVMR after acetazolamide administration in patients with TA (with and without neurologic involvement) $(5,12,13)$. No study or case report evaluating cVMR with $\mathrm{BHT}$ in patients with TA could be identified.

Although both are manifestations of large vessel involvement, cerebral hemodynamics in the course of TA do not follow the pattern observed in large vessel atherosclerosis. In patients with an increased degree of atherosclerotic carotid artery stenosis, cVMR evaluated by triggering hypercapnia $\left(5 \% \mathrm{CO}_{2}\right)$ was found to be lower than in patients with atherosclerotic carotid artery disease without stenosis (14). In another study, significantly lower cVMR and $\mathrm{BHI}$ values were found in patients with $>70 \%$ atherosclerotic carotid stenosis than in patients with $50-69 \%$ stenosis, regardless of whether they were symptomatic (15). When the stenosis worsened and became occlusive, the $\mathrm{CO}_{2}$-induced $\mathrm{CVMR}$ and dynamic cerebral autoregulatory measurements were found to be lower than the non-occluded hemispheric measurements (16). In light of these data, it can be concluded that in patients with stable TA under treatment, at least in the middle range after treatment, sVMR is normal or normalized, despite the persistence of parent large artery pathology.

\section{Conclusion}

In our study, cVMR was evaluated using the BHT in six clinically stable patients with TA with neurologic involvement, who were not surgically treated, and who were receiving immunosuppressive or biologic agents, and the relevant values were not found to be different from healthy controls. This appears to be secondary to the preservation of cerebral microcirculation in patients with TA due to the effect of treatment or regardless of treatment, possibly in contrast to atherosclerotic cervicocerebral artery occlusions.

The main limitation of our study was the small number of patients examined. The reason for this was that it was limited only to the requests made by the physicians of the patients to evaluate the risk of stroke. It was thought that it would be appropriate to report this as a pre-study considering the presence of very similar changes in all patients and the importance of these changes on drug selection. There is a need for large-scale and preferably multi-center studies that will show the temporal course of cerebral hemodynamic changes in TA starting from the earliest period and in long-term follow-up, and investigate the effect of the treatments on cVMR.

\section{Ethics}

Ethics Committee Approval: Hacettepe University Ethics Committee (project no: 20/903, decision no: 2020/16-24).

Informed Consent: Informed consent was waived due to retrospective nature of study in Takayasu patients, while informed consent was obtained in control group.

Peer-review: Externally and internally peer-reviewed.

\section{Authorship Contributions}

Surgical and Medical Practices: M.Y.P., E.M.A., M.A.T., Concept: Ö.K., E.M.A., M.A.T., Design: Ö.K., E.M.A., M.A.T., Data Collection or Processing: M.Y.P., S.R., E.Ç.B., F.K., Analysis or Interpretation: M.Y.P., E.M.A., M.A.T., Literature Search: M.Y.P., F.K., E.M.A., M.A.T., Writing: M.Y.P., E.M.A., M.A.T.

Conflict of Interest: No conflict of interest was declared by the authors.

Financial Disclosure: The authors declared that this study received no financial support. 


\section{References}

1. Cantu C, Pineda C, Barinagarrementeria F, et al. Noninvasive cerebrovascular assessment of Takayasu arteritis. Stroke 2000;31:2197-2202.

2. Dabague J, Reyes PA. Takayasu arteritis in Mexico: a 38-year clinical perspective through literature review. Int $\mathrm{J}$ Cardiol 1996;54(Suppl):S103-S109.

3. Ameriso S, Bernard JT, Weaver F, Fisher M. "Pulseless" transcranial Doppler findings in Takayasu's arteritis. J Clin Ultrasound 1990;18:592-596.

4. Grosset DG, Patterson J, Bone I. Intracranial haemodynamics in Takayasu's arteritis. Acta Neurochir (Wien) 1992;119:161-165.

5. Lee YS, Yoon BW, Roh JK. Nonpulsatile cerebral perfusion in Takayasu's arteritis. J Neuroimaging 2003;13:169-171.

6. Hall S, Barr W, Lie JT, et al. Takayasu arteritis. A study of 32 North American patients. Medicine (Baltimore) 1985;64:89-99.

7. Egido JA, Castrillo C, Sanchez M, Rabano J. Takayasu's arteritis: transcranial Doppler findings and follow-up. J Neurosurg Sci 1996;40:121-124.

8. Christiansen ME, O'Carroll CB, Kumar G, Larsen BT, Dumitrascu OM. Transcranial doppler evaluation in takayasu arteritis with oculocerebrovascular complications. Neurologist 2019;24:17-21.

9. Khasiyev F, Arsava EM, Topcuoglu MA. Cerebral vasomotor reactivity in migraine: effect of patent foramen ovale and aerogenic microembolism. Neurol Res 2020:42:795-804.
10. Serra R, Butrico L, Fugetto F, et al. Updates in pathophysiology, diagnosis and management of takayasu arteritis. Ann Vasc Surg 2016;35:210-225.

11. Li J, Yang Y, Zhao J, et al. The efficacy of Mycophenolate mofetil for the treatment of Chinese Takayasu's arteritis. Sci Rep 2016;6:38687.

12. Hiu T, Kitagawa N, Suyama K, Nagata I. Progressing takayasu arteritis successfully treated by common carotid-internal carotid crossover bypass grafting: technical case report. Neurosurgery 2008;62:E1178-9; discussion E9.

13. Zbornikova V, Lindstrom F, Lassvik C. Takayasu's disease: Ultrasonic evaluation of extracranial and intracranial hemodynamics. J Stroke Cerebrovasc Dis 1994; $4: 130-136$.

14. Ju K, Zhong L, Ni X, et al. Cerebral vasomotor reactivity predicts the development of acute stroke in patients with internal carotid artery stenosis. Neurol Neurochir Pol 2018;52:374-378.

15. Puz P, Lasek-Bal A, Urbanek T, Kazibutowska Z. Assessment of cerebral embolism and vascular reserve parameters in patients with carotid artery stenosis. Neurol Neurochir Pol 2016;50:356-362.

16. Marshall RS, Pavol MA, Cheung YK, et al. Dissociation among hemodynamic measures in asymptomatic high grade carotid artery stenosis. J Neurol Sci 2016;367:143-147. 